\title{
Determinants Of The Write-Off Decision Under IFRS: Evidence From Germany
}

Lena Siggelkow, HHL Leipzig Graduate School of Management, Germany Henning Zülch, HHL Leipsig Graduate School of Management, Germany

\begin{abstract}
This study examines the factors that influence write-off decisions in German-listed companies. Write-offs have been widely discussed, especially for the US-American market, and a relation to earnings management has been found in existing studies. German companies differentiate from the companies that have already been analyzed as they operate under different accounting standards (IFRS) and in a different institutional setting. Additionally, managers are confronted with the task to derive the IFRS annual statements from the existing annual statements according to local GAAP which follow a differing objective. Based on a sample of 805 observations of German companies listed in the DAX, MDAX, TecDax and SDAX indices between 2004 and 2010, we analyze the impact of firm performance as well as reporting incentives on the write-off decision. We find that the write-off probability rises significantly with decreasing overall firm performance, which is in line with the legal requirements. Additionally, we find a strong relation of the write-off probability with unexpectedly high earnings, which is an indicator for income smoothing. Besides influencing the shareholder's perception, income smoothing can serve to minimize overall tax payments or to influence the bank's risk assessment. In contrast with prior studies focusing on the US-American market, we found no evidence for other capital market motives, like big bath accounting and management changes; neither could we confirm the hypothesis that earnings-based management compensation or leverage have a significant influence on the write-off decision. These results indicate that German managers aim to influence tax payments and potential lenders in contrast to the perception of potential shareholders.
\end{abstract}

Keywords: Earnings Management; Write-Off Decision; Income Smoothing; Reporting Incentives

\section{INTRODUCTION}

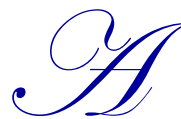

ccording to IAS 36 Impairment of Assets, companies applying International Financial Reporting Standards (IFRS) are required to perform annual tests to detect the existence of indications that the value of long-lived assets covered by the scope of the standard may be impaired. If such an indication exists, the company is required to calculate the recoverable amount and compare it to the carrying amount of the asset under consideration. Although IAS 36 provides a detailed description of how to calculate the recoverable amount, the calculation entails large areas of discretion. As the recoverable amount is usually deduced from future expected cash flows, a situation arises in which information is distributed asymmetrically because management has more information than investors regarding future strategy and development, which gives rise to earnings management (Schipper, 1989). In our study, we examine the factors that influence the write-off decision for German-listed companies.

Earnings management concerning the recognition of write-offs has been discussed in several studies. However, the existing literature has been mainly focused on the US-American market (e.g. Beatty and Weber, 2006; Francis et al., 1996; Riedl, 2004). Little research has been conducted regarding the European IFRS setting and, to the best of our knowledge, there does not exist a study on write-offs under IFRS in Germany. We concentrate on Germany for two reasons. First, their publicly listed companies have been required to prepare their consolidated financial statements based on IFRS since 2005. Second, the institutional setting in Germany varies materially from that in the USA, which may give interesting insights for other countries with similar institutional settings. 
The regulations concerning fixed asset write-offs vary between the US-GAAP and IFRS regimes, especially regarding the techniques used to decide whether a write-off is realized. ASC 360-10 Impairment and Disposal of Long-Lived Assets (formerly SFAS 144) requires a company to test the asset for recoverability as an initial step, by comparing the carrying amount with the sum of the estimated future undiscounted cash flows from further use of the asset. As a second step, the write-off amount is calculated as the difference between the carrying amount and the fair value of the asset. IAS 36 requires the company to compare the recoverable amount (the higher of value in use and fair value less costs to sell) with the carrying amount. If the carrying amount exceeds the recoverable amount, the asset is impaired and is required to be written off by the difference between the two amounts. Thus, according to IFRS, the write-off decision and the write-off amount are technically decided within the same step, while two steps are required according to US-GAAP. This may lead to differing factors influencing the write-off decision according to the two systems.

The USA can be classified as a common-law country with high shareholder protection, relatively low creditor protection, low ownership concentration, and a developed equity market; therefore, the regime is marketcentered (La Porta et al., 1998). In contrast, Germany is a code-law country with low shareholder protection, high creditor protection, high ownership concentration, and an underdeveloped equity market; therefore, it is a bankcentered regime. Leuz et al. (2003) show that companies in countries with high investor protection, low ownership concentration, and developed equity markets engage less in earnings management, suggesting different patterns of earnings management in the USA and Germany.

Additionally, the German GAAP, which are still used to prepare individual financial statements, are materially influenced by stakeholder orientation. This stakeholder orientation results in prudence being the overriding principle, which means that losses have to be realized sooner rather than later, in contrast with gains which may only be realized when they occur. Furthermore, there exists a close link between tax accounting and local GAAP, motivating companies to manipulate their individual financial statements to minimize tax payments. Even though companies are required to reconcile their individual financial statements to IFRS for the preparation of consolidated financial statements, we assume that national reporting practice influences the reporting according to IFRS; similarly, Kvaal and Nobes (2012) find that national patterns in financial reporting practice persist over time.

The results of our analysis show that the write-off decisions of German-listed companies are materially influenced by firm performance. In contrast with different studies on the US-American market, we do not find big bath accounting to be significant, but we do find that the write-off decision is materially influenced by income smoothing. This finding is of interest to local and international regulatory and supervisory bodies, as well as to shareholders, lenders and financial analysts. IFRS are designed to provide useful information for (potential) shareholders of a company. All attempts at earnings management work against the fair presentation. Hence, to receive useful information, investors need to anticipate methods to manage earnings. As Leuz et al. (2003) show, earnings management decreases in enforcement. To reduce earnings management, it is necessary to empower enforcement at specific points, which requires the government to be conscious of what methods of earnings management are used.

\section{PRIOR RESEARCH AND HYPOTHESES DEVELOPMENT}

\subsection{Prior Research}

In this section, we will give a short overview of the existing literature regarding the factors influencing the fixed asset write-offs. We are aware that there has been an extensive amount of research conducted in this area and therefore, we will concentrate our literature review on the most influential studies which use similar regression models to ours.

Most of the existing literature examines the US-American market, but little research has been done that focuses on the write-off decision itself. Minnick (2011) examines the relation of the write-off decision with corporate governance. She finds a positive relation of percentage of outside directors, shareholder protection, payperformance sensitivity, and CEO turnover with the write-off decision and a negative relation of board size and the write-off decision. By analyzing good and bad governed companies separately, she finds that write-offs of good 
governed companies are related to economic factors while those of bad governed companies are opportunistic. Additionally, she finds that good governed companies realize smaller write-offs than bad governed companies do because the latter recognize the loss only when it is so big that it cannot be ignored anymore. Loh and Tan (2002) analyze macroeconomic and firm-specific factors that influence the write-off decision of companies in Singapore. They find that the unemployment rate, the GDP growth rate, the occupancy rate of properties and management changes are important determinants, whereas variables like the debt to asset ratio seem to be less significant. Francis et al. (1996) analyze the causes of write-offs of US-American companies before the adoption of SFAS 121 Accounting for the Impairment of Long-Lived Assets and for Long-Lived Assets to be Disposed Of and find significant evidence for the influence of management changes and write-off history on the frequency and magnitude of write-offs. Interestingly, the authors additionally find evidence against the income smoothing and big bath theory, since write-offs decrease in firm-years with unexpectedly high and unexpectedly poor performance.

Riedl (2004) compares the write-off characteristics of US-American companies before and after the adoption of SFAS 121. He finds that write-offs were more closely related to management incentives and less closely related to economic effects after the change in accounting regulations. During the post-SFAS 121 period, he shows that there is a significant correlation between management changes, as well as big bath accounting, and the magnitude of write-offs, but both factors were insignificant during the pre-SFAS 121 period. Beatty and Weber (2006) conduct a two-stage analysis estimating a joint probit and censored regression to analyze factors influencing the goodwill write-off decision and write-off magnitude in the SFAS 142 Goodwill and Other Intangible Assets adoption period. What makes these write-offs special is that in the transition period, managers have to choose between a certain current write-off below the line and an uncertain future write-off included in income from continuing operations. Among other things, the authors find that where net worth covenants exclude the effect of accounting changes, the frequency and magnitude of SFAS 142 write-offs rises for firms with a relatively high risk of future write-offs if a potential future above the line write-off will be highly capitalized and if the bonus-based compensation plan explicitly excludes special items. Furthermore, the probability and magnitude of SFAS 142 write-offs decreases if the firm is traded on an exchange with explicit delisting requirements and in the tenure of the $\mathrm{CEO}$, which the authors explain by the fact that a shorter $\mathrm{CEO}$ tenure increases the probability that the actual CEO did not make the original acquisition.

Cotter et al. (1998) investigate the determinants of the magnitude of write-offs of Australian companies, focusing on management incentives. They find a significant relation between management changes and the magnitude of write-offs. They also find a relationship with the amount of cash reserves, which they interpret as the capacity to absorb write-offs. Interestingly the authors do not find a significant impact on the magnitude of writeoffs in respect of governance mechanisms, such as the existence of an audit committee and auditing by the Big Six auditors.

AbuGhazaleh et al. (2011) analyze the impact of earnings management on the goodwill write-off decision and its magnitude in the UK after the mandatory adoption of IFRS 3. The authors elaborate on the influence of corporate governance mechanisms in detail and find that goodwill write-offs are materially influenced by management incentives, like management changes, big bath accounting and income smoothing. However, due to the strong relationship between goodwill write-offs and good governance, they argue that managers use their discretion to convey private information rather than to manage earnings opportunistically. Finally, Garrod et al. (2008) analyze the write-off decision and its magnitude in small privately-held companies in Slovenia. They report that in the absence of agency problems and in an environment with high alignment between financial and tax reporting, companies tend to manage earnings using current asset write-offs, whereas fixed asset write-offs seem to be influenced mostly by regulatory factors.

\subsubsection{Development Of Hypotheses}

\subsubsection{The Write-off Decision}

According to IAS 36, a company is required to assess whether there is an indication that the asset under consideration may be impaired at the end of each reporting period. In making this assessment, as a minimum, the company is required to consider internal and external factors described in IAS 36.12 as follows: 
- $\quad$ obsolescence or physical damage of an asset

- $\quad$ significant changes in the extent to which an asset is used

- $\quad$ economic performance of the asset is worse than expected

If there is an indication that the asset may be impaired, the recoverable amount of the asset must be calculated and compared to the carrying amount. A positive difference between carrying amount and recoverable amount must be written off. The recoverable amount is defined as the higher of value in use and fair value less costs to sell, where the value in use is the present value of future cash flows from further use of the asset and its final disposal. Ideally, the fair value less costs to sell shall be derived from a binding sale agreement. If a sale agreement does not exist, it is to be derived from an active market or, failing that, from the best information available to reflect the amount that an entity could obtain, at the end of the reporting period, from the disposal of the asset in an arm's length transaction between knowledgeable willing parties, after deducting the cost of disposal. As a binding sale agreement will rarely be available and for most assets an active market does not exist, the fair value less costs to sell is typically calculated as the present value of future cash flows that a market participant could gain with the asset. In contrast to the calculation of the value in use, firm-specific factors, like synergies, may not be included.

The assessment of whether an indication exists that the asset may be impaired, as well as the calculation of the recoverable amount, requires insider knowledge with respect to the status, usage and profitability of the asset under consideration, giving the management room for individual judgment. According to Healy and Wahlen (1999), "earnings management occurs when managers use judgment in financial reporting and in structuring transactions to alter financial reports to either mislead some stakeholders about the underlying economic performance of the company or to influence contractual outcomes that depend on accounting numbers". The occurrence of earnings management thus depends on the existence of certain reporting incentives that motivate the management to manipulate earnings. We assume that the write-off decision is affected by both a decrease in the recoverable amount of the asset under the carrying amount, which we will call impairment, as well as reporting incentives.

\subsubsection{Impairment}

IAS 36 requires a write-off to be recognized whenever an asset's recoverable amount falls below the asset's carrying amount. The calculation of the recoverable amount is only required if there is an indication that the asset may be impaired. Following Cotter et al. (1998), we argue that if there is an indication that the asset may be impaired and the carrying amount exceeds the recoverable amount, the management has an incentive to write off for at least two reasons - legal liability to recognize the write-off and the comparative advantage of providing information about their firm's expected future cash flows. La Porta et al. (1998) classify Germany as a country with relatively high enforcement and therefore, non-compliance with the accounting standards is relatively risky. The identification of companies that have assets which are impaired is based on the assumption that impairment is associated with poor firm performance. Hence, we suggest our first hypothesis:

H1: The write-off probability is higher for companies with worse performance.

We include three proxies for firm performance in our analysis, the choice of which is, in part, influenced by the specification of IAS 36. Furthermore, as we have no information on the firm's estimates of future performance, we include variables measuring current performance in our analysis, as the estimates of future performance are usually based on these. The first proxy is income before write-offs. IAS 36.14 (b) states that operating profits that are worse than expected are an indicator that the asset might be impaired. Thus, we expect a negative correlation between the write-off probability and income before write-offs. As the calculation of the recoverable amount is mostly based on expected future cash flows, our second proxy for firm performance is the operating cash flow of the company. IAS 36.14 (b) also states that net cash flows that are worse than expected indicate that the asset might be impaired. Therefore, we expect a negative correlation between the write-off probability and the operating cash flow. The necessity to write off follows from the relation of market value to carrying amount. Thus, our third proxy for firm performance is the market-to-book ratio. IAS 36.12 (d) identifies a market-to-book ratio below one as an indicator that the asset under consideration is impaired. As with earnings before write-offs and the operating cash flow, we expect a negative correlation between the market-to-book ratio and the write-off probability. 


\subsubsection{Reporting Incentives}

Following Healy and Wahlen (1999), we divide reporting incentives into two broad groups - capital market motivations and contracting motivations. We do not explicitly analyze regulatory requirements since we do not partition our sample by industries. We incorporate overall regulations in our analysis through control variables such as firm size.

\subsubsection{Capital Market Motivations}

The perception of the company by stock market participants is probably one of the most important targets for management since actual and potential shareholders control the share price. Therefore, positively influencing their perception is probably one of management's main incentives. One way to achieve this goal might be to manage current year's earnings performance. Following the extensive income smoothing literature, we assume that good earnings performance is related to a high write-off probability. The idea behind this is that the management tries to meet the shareholders' expectations. According to Moses (1987), we can define income smoothing as an "effort to reduce fluctuations in reported earnings", meaning that the management uses the write-off decision as a "smoothing device" to reduce the divergence of reported earnings from the expected number. The notion of income smoothing is based on the assumption that shareholders perceive actual earnings as a signal for future earnings and that smoothed earnings allow for more precise forecasts, which the capital market rewards with higher share prices. In support of this assumption, Kasznik and McNichols (1999) report that even though financial analysts do not adjust their forecasts for companies that consecutively meet their expectations, the market grants a market premium.

In the German setting, there are two further arguments for income smoothing. Regarding the individual annual statements, high tax-book conformity exists. According to Graham and Smith (1999), high tax-book conformity is an incentive to smooth earnings because it reduces overall tax expenses under a progressive tax rate. Since we assume that not all earnings management will be undone in the reconciliation process, the income smoothing in individual annual statements will impact the consolidated financial statements according to IFRS. The second argument is that debt financing is relatively important in Germany because the equity market is underdeveloped. According to Trueman and Titman (1988), material debt financing is an incentive to smooth earnings because if the lender observes a low volatility in the company's earnings, the assessment of the probability of bankruptcy is lowered, which in turn results in decreased borrowing costs.

Some empirical studies (e.g. Francis et al., 1996) find significant evidence for the existence of income smoothing in the write-off decision, but other studies find that there is no such relationship (e.g. Riedl, 2004). We assume that managers apply income smoothing, meaning that impairment losses will be recognized in years with unexpectedly high income before impairment losses:

H2: Companies with unexpectedly high earnings before write-offs have a higher write-off probability.

Closely related to the assumption of income smoothing is that of big bath accounting. Big bath accounting means that the management accumulates problems until it finally recognizes a huge write-off in a year in which the company has realized an unexpectedly low income anyway. Following this approach offers several advantages (see Strong and Meyer, 1987). First, management in this way establishes a safety cushion for subsequent years in which it will be easier to meet the shareholders' expectations. Second, it is argued that recognizing a large one-time loss signals that past problems have been solved. The third advantage is merely arithmetic - lowering earnings in the current year ensures high earnings growth for the future. Another more psychological argument on which the big bath technique may be based is that if the situation is already bad, making it a little worse will, in most cases, do no harm either to management reputation or to earnings expectations (see Walsh et al., 1991). Thus, we assume that managers apply big bath accounting, meaning that write-offs will be realized in years with unexpectedly low income before write-offs:

H3: Companies with unexpectedly low earnings before write-offs have a higher write-off probability. 
While H2 and H3 seem to be contradictory at first sight, Kirschenheiter and Melumad (2002) prove that if the reporting environment permits discretion, the optimal strategy of management is to smooth income if good news occurs and use big bath accounting if bad news occurs.

Another incentive that influences the write-off decision is a change in management. There are different reasons for incoming managers to recognize write-offs in their first year (see Wells, 2002). One of these is that they are not held responsible for past performance and thus, they may explicitly attribute the write-off to the preceding management. This is often referred to as "cleaning the decks", illustrating the fact that new managers tend to recognize write-offs that have been delayed in prior years. In this way, it is possible to anticipate future losses without any loss of reputation, resulting in increasing earnings in subsequent years. The result of high write-offs in the first year is that income in future years is relieved of these expenses so that an improving earnings trend can be reported from the first year of tenure onwards. In support of this theory, Moore (1973) finds that companies with recent management changes show a significantly greater proportion of income-reducing discretionary accounting decisions. A number of studies report the same result for the relationship between management changes and writeoffs (e.g. Beatty and Weber, 2006; Francis et al., 1996; Riedl, 2004), whereas others find no significant relationship (e.g. Cotter et al., 1998).

H4: Firm-years in which a management change has occurred have a higher write-off probability.

\subsubsection{Contracting Motivations}

There are different kinds of contracts that rely on accounting data. Two kinds that are frequently used are credit agreements and management compensation contracts, where credit agreements are usually tied to leverage and management compensation contracts often refer to earnings. The leverage of the company under consideration may influence credit agreements in two ways. First, the level of borrowing costs is based on the assessment of financial risk for which leverage is an important determinant, meaning that higher leverage can result in higher borrowing costs. Second, most credit agreements contain strict regulations concerning leverage, called debt covenants. The breach of a given covenant can lead to an immediate repayment claim from the creditor, which would result in extensive liquidity problems for most companies. Following the results of Duke and Hunt (1990), leverage can be used as a proxy for the closeness to debt covenant restrictions. Sweeney (1994) also provides evidence in support of the hypothesis that managers of firms approaching technical default respond with income-increasing accounting changes. Regarding the write-off decision, this means that the write-off probability decreases, delivering our fifth hypothesis:

H5: Companies with higher leverage have a lower write-off probability.

Management compensation is commonly divided into a fixed and a variable part, where the latter has a short-term and a long-term component. The short-term component is usually based on a measure of the company's success, whereas the long-term component contains a stock-option plan. If write-offs influence the figure standing for success (e.g. EBIT, profit), we assume that the management has an incentive to delay write-offs to later years in order to increase the current period's income (see Watts and Zimmerman, 1978). Similarly, Beatty and Weber (2006) find that bonus plans that do not explicitly exclude write-offs reduce the write-off probability. Therefore, our sixth hypothesis is as follows:

H6: Companies which grant managers earnings-based bonuses that are affected by write-offs have a lower write-off probability.

\section{RESEARCH DESIGN}

\subsection{Sample Selection}

Our full sample is comprised of all the non-financial German companies that were listed in the German DAX, MDAX, TecDax and SDAX indices between 2004 and 2010, with a complete IFRS dataset available in the Worldscope database. To be able to calculate variables that refer to previous year data, such as expected earnings, 
we had to exclude the first observation and the first observation after a gap for all companies. Our full sample contains 165 firms, providing 805 firm-years. To test for the influence of management changes and earnings-based bonus payments, we hand-collected information on these two variables as described below for all companies that were listed in HDAX (a combination of DAX, MDAX and TecDax) between 2004 and 2010. Therefore, we excluded from the sample all companies that were not listed in HDAX during the period under consideration and additionally had to exclude a further 170 and 182 observations for the management change sample and the earningsbased bonus sample, respectively, due to a lack of information. Table 1 (see Appendix) describes the process of sample selection for all three samples.

\subsubsection{Model and Variable Measurement}

Since the decision to write off is a dichotomous variable, we used a probit regression to examine the influence of the impairment and reporting incentives described above on the write-off decision. We include multiple firm-years of the companies examined in our analysis and thus apply a panel research design. To implement our analysis, we use the following random effects probit regression:

$$
\begin{aligned}
\operatorname{Pr}\left(\text { WO }_{i t}=1\right)= & \beta_{0}+\beta_{1} \text { INCOME }_{i t}+\beta_{2} \text { OCF }_{i t}+\beta_{3} \text { MTB }_{i t} \\
& +\beta_{4} \text { BIGBATH }_{i t}+\beta_{5} \text { INCSMOOTH }_{i t}+\beta_{6} \text { DTA }_{i t} \\
& +\beta_{7} \text { FIRMSIZE }_{i t}+\beta_{8} \text { BIG }_{i t}+\beta_{9} \text { LISTING }_{i t}+\beta_{10-15} \text { YEAR }_{t}+\varepsilon_{i t} .
\end{aligned}
$$

To test the influence of management changes, we run the following probit regression on our management change sample:

$$
\begin{aligned}
\operatorname{Pr}\left(\text { WO }_{i t}=1\right)= & \beta_{0}+\beta_{1} \text { INCOME }_{i t}+\beta_{2} \text { OCF }_{i t}+\beta_{3} \text { MTB }_{i t} \\
& +\beta_{4} \text { BIGBATH }_{i t}+\beta_{5} \text { INCSMOOTH }_{i t}+\beta_{6} \text { DTA }_{i t}+\beta_{7} \text { MC C }_{i t} \\
& +\beta_{8} \text { FIRMSIZE }_{i t}+\beta_{9} \text { BIG4 }_{i t}+\beta_{10} \text { LISTING }_{i t}+\beta_{11-16} \text { YEAR }_{t}+\varepsilon_{i t} .
\end{aligned}
$$

Similarly, to analyze the influence of earnings-based bonus payments, we run the following probit regression on our earnings-based bonus sample:

$$
\begin{aligned}
\operatorname{Pr}\left(W_{i t}=1\right)= & \beta_{0}+\beta_{1} \text { INCOME }_{i t}+\beta_{2} \text { OCF }_{i t}+\beta_{3} \text { MTB }_{i t} \\
& +\beta_{4} \text { BIGBATH }_{i t}+\beta_{5} \text { INCSMOOTH }_{i t}+\beta_{6} \text { DTA }_{i t}+\beta_{7} \text { EBB }_{i t} \\
& +\beta_{8} \text { FIRMSIZE }_{i t}+\beta_{9} \text { BIG4 }_{i t}+\beta_{10} \text { LISTING }_{i t}+\beta_{11-l 6} \text { YEAR }_{t}+\varepsilon_{i t} .
\end{aligned}
$$

The endogenous variable, $W O_{i t}$, is a dichotomous variable that takes the value of 1 if company i recognizes a write-off in $t$ and takes the value of 0 otherwise. We calculate total write-offs as the sum of write-offs on goodwill, other intangibles and property, plant and equipment. In contrast to Garrod et al. (2008), current asset write-offs are not included in the analysis as they are excluded from the scope of IAS 36. Hence, the dichotomous variable, $W O_{i t}$, is equal to 1 whenever total write-offs exceed 0 . We decided to represent the independent non-indicator variables as ratios rather than as levels to control for scale. Thus, $I N C O M E_{i t}$ represents the net income of company i in $\mathrm{t}$ corrected for any write-offs divided by total assets of company $\mathrm{i}$ in $\mathrm{t}-1 . O C F_{i t}$ is company i's operating cash flow in $\mathrm{t}$ divided by total assets of company i int- $1 . M T B_{i t}$ represents company i's market-to-book ratio in t. Similar to Francis et al. (1996), to proxy for income smoothing and big bath accounting, we first calculate an earnings management indicator, $E M I_{i t}$, which is the difference of company i's net income in t corrected for taxes and write-offs and company i's earnings before taxes in t- 1 divided by company i's total assets in t- 1 . The definition of the earnings management indicator is based on the choice of a random walk model for the development of earnings before taxes, predicting actual earnings being equal to last year's earnings (see Moses, 1987). If the earnings before taxes and write-offs in t are unexpectedly high, the earnings management indicator takes a positive value; if they are unexpectedly low, it is negative. INCOMESMOOTH $H_{\text {it }}$ proxies for income smoothing of company $\mathrm{i}$ in $\mathrm{t}$. It takes the value of the earnings management indicator, $E M I_{i t}$ if this exceeds 0 and is 0 otherwise. We do not proxy for income smoothing using a dichotomous variable because if the management tries to smooth earnings, the necessity to write off rises with the degree to which actual and expected earnings deviate. Similarly, BIGBATH ${ }_{i t}$ proxies for big bath accounting of company $\mathrm{i}$ in $\mathrm{t}$ and equals the earnings management indicator, $E M I_{i t}$, if this falls below 0 and is 0 otherwise. As the choice of the ratio used to proxy for leverage does not play an important role (see Duke and Hunt, 
1990), we use $D T A_{i}$, which represents the ratio of total debt of company $\mathrm{i}$ in $\mathrm{t}$ divided by total assets of company $\mathrm{i}$ in t.

The variables $M C_{i t}$ and $E B B_{i t}$ were hand-collected. Healy (1985) argues that compensation plans will generally contain upper and lower bounds and prove that management has an incentive to choose income-increasing accruals (i.e., no write-off) only if neither the lower nor the upper bound defined in the bonus plan is binding. If one of these bounds is binding, the management has an incentive to choose income-decreasing accruals (i.e., to write off) in order to maximize their future payments. We collected the information on compensation plans from annual reports. Due to a lack of information on bounds or exact measurement for the earnings-based compensation, we decided to proxy for earnings-based bonus payments using the dichotomous variable, $E B B_{i}$, which equals 1 if the management receives earnings-based bonus payments that are affected by write-offs and is 0 otherwise. We exclude those firm-years for which we only found general statements in the annual reports. The information on management changes was collected from the home page of the DGAP Deutsche Gesellschaft für Ad-hoc-Publizitaet mbH, which is a portal that companies can use to fulfill the duty to publish ad hoc disclosures. $M C_{i t}$ is a dichotomous variable that equals 1 if changes in the management board of company $i$ occurred in $t$ and is 0 otherwise. Companies that do not use the services of DGAP were excluded from the sample.

In addition to the variables measuring the hypothesized effects, we included some control variables measuring other factors that could influence the tendency to write off. Following the existing literature, we include measures for company- size, the size of the auditor and listing on foreign stock exchanges. FIRMSIZE ${ }_{i t}$ is the natural logarithm of the total assets of company $\mathrm{i}$ in t. $B I G 4_{i t}$ is a dichotomous variable equal to 1 if company $\mathrm{i}$ was audited by a Big 4 Four audit company in $\mathrm{t}$ and 0 otherwise. Finally, LISTING $_{i t}$ is an indicator variable equal to 1 if company $\mathrm{i}$ was listed on a foreign stock exchange in $\mathrm{t}$ and 0 otherwise. $Y E A R_{t}$ are dummy variables for the observation year, which we included to control for macroeconomic effects.

\section{RESULTS}

\subsection{Descriptives And Correlation Analysis}

Table 2 (see Appendix) provides descriptive statistics for our sample firms.

We find that a write-off was realized in about $60 \%$ of our sample firms-years. Average income before write-offs amounts to $4 \%$ of lagged total assets, and average operating cash flow is about $9 \%$ of lagged total assets. The mean market-to-book ratio amounts to 2.56 . We further find that the average leverage amounts to $20.82 \%$. In about $83 \%$ of our earnings-based bonus payments sample-firm-years, managers received earnings-based bonus payments that were affected by write-offs. In about $26 \%$ of the management change sample-firm-years, a management change had occurred.

Table 3 (see Appendix) partitions the observations according to those firm-years in which a write-off was recognized and those in which there was no write-off.

Regarding the impairment variables, we find the net income before write-offs to be significantly higher for non-write-off firm-years than for write-off firm-years; this is consistent with prior research. Interestingly, we do not find significant differences in mean values between the two groups in respect of operating cash flow and market-tobook ratio, indicating that managers base their write-off decision on earnings measures rather than on cash flow measures. Regarding the reporting incentives, we find significant differences in the means of leverage, management change and earnings-based bonus payments. Contrary to our expectations, the mean leverage is higher for write-off firm-years than for non write-off firm-years, which argues against Hypothesis 5 that the managers of companies with high leverage will try to delay write-offs. Instead, it supports the impairment hypothesis that companies in a worse financial situation; i.e., which are higher leveraged, will have a higher write-off probability. As expected, the mean management change indicator is significantly higher for write-off firm-years, indicating that incoming managers tend to realize write-offs either to clean the decks or to anticipate future losses, or both. Consistent with our expectations, the mean earnings-based bonus payment indicator is significantly lower for write-off firm-years, suggesting that managers who receive compensations that do not exclude write-off effects write off less frequently 
than managers whose compensation is not affected by write-offs. We do not find significant differences in terms of our big bath proxy or our income smooth proxy. Additionally, we find that write-off firm-years are associated with significantly higher company size, higher frequency of auditing by a Big Four audit company, and listing on a foreign exchange.

Table 4 (see Appendix) reports the pairwise Pearson and Spearman correlation coefficients for all variables analyzed. The correlations are relatively low, showing that our results are not influenced by multicolliniarity.

\subsection{Regression Results}

\subsubsection{Impairment Variables}

Table 5 (see Appendix) presents the results from our three probit regressions.

Regarding the impairment variables, we find net income before write-offs to be significant at the $1 \%$ level for all three models. The sign is negative as predicted, indicating that lower income is associated with higher writeoff probability. This confirms Hypothesis 1 that the write-off probability rises with decreasing firm performance. Operating cash flow is insignificant for all three models. This result shows that contrary to what the standard-setter requires, the write-off decision does not seem to be based on the expected cash flows but on the accruals-based measure of income before write-offs. Alternatively, this insignificance could result from using the overall operating cash flow as proxy for the free cash flow generated by the assets tested for write-offs.

Contrary to our expectations, the market-to-book ratio has a positive sign for all three models, indicating that the write-off probability increases with increasing market-to-book ratio. However, this result is significant at the $10 \%$ level for model 1 and model 3 only, and completely insignificant in model 2, including the management change indicator. Thus it is not very robust. The positive sign could indicate that the market-to-book ratio cannot be interpreted as an indicator for the market value of the asset being higher than its book value, resulting in no necessity to write-off, but instead it should be interpreted as a measure for growth options. Cotter et al. (1998) argue that a high market-to-book ratio results from high growth options and that companies with high growth options are riskier and thus more susceptible to write-offs.

\subsubsection{Reporting Incentives}

Regarding the reporting incentives, we find a significant positive influence of income smoothing at the $1 \%$ level for models 1 and 3 and at the 5\% level for model 2, while big bath and leverage are insignificant for all three models. Thus, our findings support Hypothesis 2 while we have to reject Hypotheses 3 and 5. Analyzing the USAmerican market, Riedl (2004) found the opposite results, with a significant negative influence of unexpectedly low earnings being a sign of big bath accounting - a significant negative influence of leverage supporting his debtcovenant hypothesis and no significant influence of income smoothing.

The insignificance of big bath in this study could result from the German setting. As stated earlier, German companies' individual financial statements are driven by prudence and creditor protection, as well as the attempt to minimize tax payments. These factors result in a tendency to recognize expenses sooner rather than later and in good years rather than in bad. Due to credibility considerations, the early realization of losses in the individual and tax statements also results in an early realization of losses in the consolidated financial statements according to IFRS. The insignificance of leverage could result from the assumption that leverage can be used to proxy for the closeness to debt covenants. Additionally, German companies historically rely heavily on debt and a high leverage, in most cases, leads to the banks being more attentive to possible earnings-increasing procedures, thereby reducing the room for earnings management. Regarding the management change variable in model 2, we could not find a significant influence, indicating that German managers do not tend to realize write-offs in their first year. The insignificance could also result from the fact that we considered all changes in the management board to be of interest and did not differentiate between different positions or situations. The earnings-based bonus payment indicator in model 3 is just below the $10 \%$ level of significance (i.e., 11.4\%). This insignificance could result from the fact that we did not account for caps and floors of the compensation plans due to a lack of information. 


\subsubsection{Control Variables}

We find a significant positive relationship between the write-off probability and the company size in all three models. Auditing by a Big Four audit company has a significant influence in model 2 at the 5\% level, but is insignificant in models 1 and 3 . The indicator for listing on a foreign stock exchange is only marginally significant in model 1 and insignificant in models 2 and 3. Untabulated year-dummies have positive signs (except for 2007 which is negative), but all are insignificant except for 2006 in model 1. As the financial crises had not begun in 2006 but GDP was rising significantly instead, the significant positive influence could result either from income smoothing or from a learning effect after mandatory IFRS-adoption in 2005. In model 2, 2006 is also insignificant and 2007 becomes positive, while 2008 and 2009 are negative. In model 3, all year dummies are positive. The year 2006 is significant at the $1 \%$ level and 2008 becomes significant at the $10 \%$ level. This could be interpreted as the influence of the financial crises, but it is a weak result due to a lack of robustness.

\subsection{Sensitivity}

To validate our findings, we conducted a series of sensitivity analyses. Results are presented in Table 6 (see Appendix).

We replaced net income before write-offs with the return on assets, operating cash flow with sales and the market-to-book ratio with the change in market-to-book ratio compared with the preceding year. Additionally, we estimated our model using a panel logit regression. Finally, we excluded all observations from 2005 because that was the year of mandatory IFRS adoption. Net income (or return on assets), the income smooth variable and company size remained significant at the $1 \%$ level through all variations. The operating cash flow becomes marginally significant with a positive sign if we include market-to-book ratio change instead of market-to-book ratio, but it remains insignificant in all other model specifications. A positive influence of operating cash flow on the write-off probability implies that the operating cash flow does not proxy for impairment but for the capacity to absorb write-offs, as Cotter et al. (1998) argue. The significance of market-to-book ratio fluctuates from $4.4 \%$ to $16 \%$ between the different variations, always with a positive sign. Market-to-book ratio change is insignificant. Big bath and leverage remain insignificant through all model variations as well as auditing by a Big Four audit company. The indicator variable for the listing on a foreign stock exchange falls just below the $10 \%$ significance level if we include the return on assets instead of the income before write-offs. Overall, we find that the write-off decision is materially influenced by income before write-offs, income smoothing and the firm size and that this main result is not altered by different model variations.

\section{CONCLUSIONS}

This study investigates the factors that influence write-off decisions in German companies applying IFRS. We find that the write-off probability materially increases in situations of decreasing net income before write-offs and in a context of increasing firm size. Furthermore, the write-off decision is materially influenced by income smoothing. Overall, our findings support the hypothesis that earnings management behavior in Germany materially deviates from that in Anglo-American countries like the USA. The write-off decision is materially influenced by income smoothing, while other reporting incentives do not have a significant impact. In contrast to prior studies most of which analyze the US-American market - we could find no evidence for big bath accounting and neither were there relationships between write-offs and earnings-based bonus payments, management changes or leverage.

Our study contributes to the existing literature in several ways. First, only a minimal amount of research has been conducted regarding the write-off decision under IFRS, with the existing research mainly focusing on the USAmerican market. As there are material differences between US-GAAP and IFRS, especially regarding the write-off decision, our study gives insights into the importance of earnings management in the application of IAS 36 . Second, we analyze the write-off behavior in a different institutional setting. Germany is a bank-centered code-law country with low shareholder protection, high creditor protection, high ownership concentration and an underdeveloped equity market. Therefore, the incentives for earnings management are likely to be very different for German firms than for US-American firms since the USA is a market-centered common-law country with high shareholder protection, relatively low creditor protection, low ownership concentration and a developed equity market. 
Our results are of interest to German regulatory and supervisory bodies as they prove that German companies apply significant discretion in their write-off decisions, which could possibly be decreased by focusing enforcement on this special issue. Additionally, our findings should be of interest to all shareholders and lenders, as well as financial analysts, in interpreting financial reports according to IFRS. Further, the results are of interest to the IASB as we provide evidence that the regulation gives room for earnings management and its use in Germany.

However, our study is subject to some limitations. First, our definition of the management change variable is based on the assumption that all changes in the management board matter. A further analysis of changes in different positions on the management board could provide further insight into the influence of management changes. Second, the definition of the earnings-based compensation variable does not include the fact that most compensation plans have caps and floors. If this information was available and included in a similar study, additional insight could be gained regarding the impact of management compensation. Finally, because we only analyzed German publicly listed companies, we could not analyze the effect of different institutional settings. Therefore, we cannot definitely identify what leads German companies to apply income smoothing extensively whether it results from being bank-centered, from tax-book conformity, or from other factors. Hence, in future research, it could be interesting to analyze the write-off decision under IFRS in a set of European companies.

\section{ACKNOWLEDGMENTS}

We thank the participants of the $34^{\text {th }}$ Annual Meeting of the European Accounting Association (EAA) as well as four anonymous reviewers for their valuable comments.

\section{AUTHOR INFORMATION}

Lena Siggelkow is a Ph.D. Student at the Chair of Accounting and Auditing at HHL Leipzig Graduate School of Management. Her main research interest is the accounting for fixed asset impairments across Europe. E-mail: lena.siggelkow@hhl.de (Corresponding Author)

Prof. Dr. Henning Zuelch is Full Professor for Accounting and Auditing at HHL Leipzig Graduate School of Management. His main teaching focus is in the fields of international accounting (IFRS), auditing and corporate governance. Research interests of Henning Zuelch comprise aspects of Financial Accounting and Disclosures with special focus on IFRS-Accounting. Research areas of him are concretely 'Consolidation', 'Performance Reporting', 'Standard Setting and Enforcement' and 'Accounting in Private Firms'. E-mail: henning.zuelch@hhl.de

\section{REFERENCES}

1. AbuGhazaleh, Naser M., et al., 'Accounting Discretion in Goodwill Impairments: UK Evidence,' Journal of International Financial Management and Accounting (Vol. 22, Issue 3, 2011), pp. 165-204.

2. Beatty, Anne and Weber, Joseph, 'Accounting Discretion in Fair Value Estimates: An Examination of SFAS 142 Goodwill Impairments,' Journal of Accounting Research (Vol. 44, Issue 2, 2006), pp. 257-288.

3. Cotter, Julie, et al., 'An Analysis of Factors Influencing Asset Writedowns,' Accounting and Finance (Vol. 38, Issue 2, 1998), pp. 157-179.

4. Duke, Joanne C. and Hunt III, Herbert G., 'An Empirical Examination of Debt Covenant Restrictions and Accounting-Related Debt Proxies,' Journal of Accounting and Economics (Vol. 12, Issue 1-3, 1990), pp. 45-63.

5. $\quad$ Francis, Jennifer, et al., 'Causes and Effects of Discretionary Asset Write-Offs,' Journal of Accounting Research (Vol. 34, Issue 3, 1996), pp. 117-134.

6. Garrod Neil, et al., 'Asset Write-Offs in the Absence of Agency Problems,' Journal of Business Finance \& Accounting (Vol. 35, Issue 3-4, 2008), pp. 307-330.

7. Graham, John R. and Smith, Clifford W. jr., 'Tax Incentives to Hedge,' Journal of Finance (Vol. 54, Issue 6, 1999), pp. 2241-2262.

8. Healy, Paul M., 'The Effect of Bonus Schemes on Accounting Decisions,' Journal of Accounting and Economics (Vol. 7, Issue 1-3, 1985), pp. 85-107. 
9. Healy, Paul M. and Wahlen, James M., 'A Review of the Earnings Management Literature and Its Implications for Standard Setting,' Accounting Horizons (Vol. 13, Issue 4, 1999), pp. 365 - 383.

10. Kasznik, Ron and McNichols, Maureen F., 'Does Meeting Expectations Matter? Evidence from Analyst Forecast Revisions and Share Prices,' Journal of Accounting Research (Vol. 40, Issue 3, 1999), pp. 727759.

11. Kirschenheiter, Michael and Melumad, Nahum D., 'Can "Big Bath" and Earnings Smoothing Co-exist in Equilibrium Financial Reporting Strategies?,' Journal of Accounting Research (Vol. 40, Issue 3, 2002), pp. 761-796.

12. Kvaal, Erlend and Nobes, Christopher, 'IFRS Policy Changes and the Continuation of National Patterns of IFRS Practice', European Accounting Review (Vol. 21, Issue 2, 2012), pp. 343-371.

13. La Porta, Rafael, et al., 'Law and Finance,' Journal of Political Economy (Vol. 106, Issue 5, 1998), pp. 1113-1155.

14. Leuz, Christian, et al., 'Earnings Management and Investor Protection: An International Comparison,' Journal of Financial Economics (Vol. 69, Issue 3, 2003), pp. 505-527.

15. Loh, Alfred L.C. and Tan, Tin H., 'Asset Write-Offs - Managerial Incentives and Macroeconomic Factors,' Abacus (Vol. 38, Issue 1, 2002), pp. 134-151.

16. Minnick, Kristina, 'The role of corporate governance in the write-off decision,' Review of Financial Economics (Vol. 20, Issue 4, 2011), pp. 130-145.

17. Moore, Michael L., 'Management Changes and Discretionary Accounting Decisions,' Journal of Accounting Research (Vol. 11, Issue 1, 1973), pp. 100-107.

18. Moses, Douglas O., 'Income Smoothing and Incentives: Empirical Tests Using Accounting Changes,' The Accounting Review (Vol. 62, Issue 2, 1987), pp. 358-377.

19. Riedl, Edward J., 'An Examination of Long-Lived Asset Impairments,' The Accounting Review (Vol. 79, Issue 3, 2004), pp. 823-852.

20. Schipper, Katherine, 'Commentary on Earnings Management,' Accounting Horizons (Vol. 3, Issue 4, 1989), pp. 91-102.

21. Strong, John S. and Meyer, John R., 'Asset Writedowns: Managerial Incentives and Security Returns,' The Journal of Finance (Vol. 42, Issue 3, 1987), pp. 643-661.

22. Sweeney, Amy P., 'Debt-covenant Violations and Managers' Accounting Response,' Journal of Accounting and Economics (Vol. 17, Issue 3, 1994), pp. 281-308.

23. Trueman, Brett and Titman, Sheridan, 'An Explanation for Accounting Income Smoothing,' Journal of Accounting Research (Vol. 26, Issue 3, 1988), pp. 127-139.

24. Walsh, Paul, et al., "'Big Bath Accounting“" using Extraordinary Items Adjustments: Australian Empirical Evidence,' Journal of Business Finance \& Accounting (Vol. 18, Issue 2, 1991), pp. 173-189.

25. Watts, Ross L. and Zimmerman, Jerold L., 'Towards a Positive Theory of the Determination of Accounting Standards,' The Accounting Review (Vol. 53, Issue 1, 1978), pp. 112-134.

26. Wells, Peter A., 'Earnings Management Surrounding CEO Changes,' Accounting and Finance (Vol. 42, Issue 2, 2002), pp. 169-193. 


\section{APPENDIX}

Table 1: Sample Selection

\begin{tabular}{|c|c|c|c|c|c|c|}
\hline & \multicolumn{2}{|c|}{ Full Sample } & \multicolumn{2}{|c|}{ Management Change Sample } & \multicolumn{2}{|c|}{$\begin{array}{c}\text { Earnings-Based Bonus Payments } \\
\text { Sample }\end{array}$} \\
\hline & Companies $^{\mathbf{b}}$ & \begin{tabular}{|l|} 
Firm-Years \\
\end{tabular} & Companies $^{\mathbf{b}}$ & \begin{tabular}{|l|} 
Firm-Years \\
\end{tabular} & Companies $^{\mathbf{b}}$ & Firm-Years \\
\hline $\begin{array}{l}\text { Companies Listed In DAX, MDAX, Tecdax Or SDAX Between } \\
2004 \text { And } 2010\end{array}$ & 229 & 1603 & 229 & 1603 & 229 & 1603 \\
\hline Financial companies & $(35)$ & $(245)$ & $(35)$ & $(245)$ & $(35)$ & $(245)$ \\
\hline Not German & $(17)$ & $(119)$ & $(17)$ & $(119)$ & $(17)$ & $(119)$ \\
\hline No complete dataset & & $(166)$ & & $(166)$ & & $(166)$ \\
\hline No IFRS & & $(88)$ & & $(88)$ & & $(88)$ \\
\hline First firm-years ${ }^{\mathrm{a}}$ & & $(180)$ & & $(180)$ & & $(180)$ \\
\hline Non-HDAX company & & & $(47)$ & $(223)$ & $(47)$ & $(223)$ \\
\hline No sufficient data on management changes & & & & $(170)$ & & \\
\hline No sufficient data on earnings-based bonus payments & & & & & & $(182)$ \\
\hline Final sample of firm-years & 165 & 805 & 85 & 412 & 98 & 400 \\
\hline
\end{tabular}

${ }^{\mathrm{a}}$ For the calculation of ratios that revert to previous year data the first observation of each company and the first observation after a gap in the data had to be excluded.

The number of companies excluded from the sample is given for financial, foreign and non-HDAX companies only, as the other criteria usually change from year to year and

thus do not result in the exclusion of a whole company on a stand-alone basis. However, the combination of different exclusion criteria might well result in the complete exclusion

of a company. Therefore, the final sample of firms cannot be calculated from the numbers given above because the sample reduced due to companies that were eliminated

cumulatively because of an incomplete dataset, no IFRS, the first reporting periods and a lack of sufficient data on management changes/earnings-based bonus payments. 
Table 2: Descriptive Statistics

\begin{tabular}{|c|c|c|c|c|c|c|c|c|}
\hline & Mean & $\begin{array}{l}\text { Standard } \\
\text { Deviation }\end{array}$ & Minimum & $\begin{array}{c}25 \%- \\
\text { Quantile }\end{array}$ & Median & $\begin{array}{c}75 \%- \\
\text { Quantile }\end{array}$ & Maximum & $\mathbf{N}$ \\
\hline $\mathrm{WO}_{\text {it }}$ & 0.60 & 0.49 & 0.00 & 0.00 & 1.00 & 1.00 & 1.00 & 805 \\
\hline INCOME $_{\text {it }}$ & 0.04 & 0.14 & -0.88 & 0.01 & 0.04 & 0.09 & 1.28 & 805 \\
\hline $\mathrm{OCF}_{\mathrm{it}}$ & 0.09 & 0.11 & -0.59 & 0.05 & 0.08 & 0.13 & 0.54 & 805 \\
\hline MTB $_{\text {it }}$ & 2.56 & 2.48 & -1.84 & 1.28 & 1.93 & 2.92 & 28.57 & 805 \\
\hline BIGBATH $_{\text {it }}$ & -0.03 & 0.07 & -0.79 & -0.02 & 0.00 & 0.00 & 0.00 & 805 \\
\hline INCSMOOTH $_{\text {it }}$ & 0.05 & 0.12 & 0.00 & 0.00 & 0.01 & 0.05 & 1.58 & 805 \\
\hline DTA $_{\text {it }}$ & 20.82 & 16.50 & 0.00 & 6.74 & 18.74 & 31.69 & 98.02 & 805 \\
\hline $\mathrm{MC}_{\mathrm{it}}$ & 0.26 & 0.44 & 0.00 & 0.00 & 0.00 & 1.00 & 1.00 & 412 \\
\hline $\mathrm{EBB}_{\text {it }}$ & 0.83 & 0.38 & 0.00 & 1.00 & 1.00 & 1.00 & 1.00 & 400 \\
\hline FIRMSIZE $_{\text {it }}$ & 14.10 & 1.89 & 9.45 & 12.77 & 13.86 & 15.05 & 19.38 & 805 \\
\hline $\mathrm{BIG}_{\text {it }}$ & 0.83 & 0.37 & 0.00 & 1.00 & 1.00 & 1.00 & 1.00 & 805 \\
\hline LISTING $_{\text {it }}$ & 0.10 & 0.30 & 0.00 & 0.00 & 0.00 & 0.00 & 1.00 & 805 \\
\hline
\end{tabular}

Table 2 provides descriptive statistics for the sample observations.

Variable definitions:

$\mathrm{WO}_{\text {it }}$

$\mathrm{INCOME}_{\mathrm{it}}$

$\mathrm{OCF}_{\text {it }}$

$\mathrm{MTB}_{\text {it }}$

BIGBATH $_{\text {it }}$

INCSMOOTH $_{\text {it }}$

DTA $_{\text {it }}$

$\mathrm{MC}_{\mathrm{it}}$

$\mathrm{EBB}_{\text {it }}$

FIRMSIZE $_{\text {it }}$

BIG4 $_{\text {it }}$

LISTING $_{\text {it }}$
$=$ an indicator variable equal to 1 if company $\mathrm{i}$ recognized a write-off in $\mathrm{t}$ and 0 otherwise

$=$ net income of company $\mathrm{i}$ in $\mathrm{t}$ corrected for impairment losses recognized by company $\mathrm{i}$ in $\mathrm{t}$ divided by total assets of company $\mathrm{i}$ in $\mathrm{t}-1$ of company $\mathrm{i}$ in $\mathrm{t}$

$=$ the operating cash flow from company $\mathrm{i}$ in $\mathrm{t}$ divided by total assets of company $\mathrm{i}$ in $\mathrm{t}-1$

$=$ the market-to-book ratio of company $\mathrm{i}$ in $\mathrm{t}$

= proxy for unexpectedly low earnings equal to EMI if EMI $<0$ and 0 otherwise

$=$ proxy for unexpectedly high earnings equal to EMI if EMI $>0$ and 0 otherwise

$=$ the total debt of company $\mathrm{i}$ in $\mathrm{t}$ divided by total assets of company $\mathrm{i}$ in $\mathrm{t}$

$=$ an indicator variable equal to 1 if a management change occurred at company $i$ in $t$ and 0 otherwise

$=$ an indicator variable equal to 1 if company i's management received earnings-based bonus payments in $\mathrm{t}$ and 0 otherwise

$=$ the natural logarithm of the total assets of company $\mathrm{i}$ in $\mathrm{t}$

$=$ an indicator variable equal to 1 if company $\mathrm{i}$ was audited by a Big Four audit company

(PricewaterhouseCoopers, KPMG, Ernst \& Young, Deloitte) in t and 0 otherwise

$=$ an indicator variable equal to 1 if company $\mathrm{i}$ was listed on a foreign stock exchange in $\mathrm{t}$ and 0 otherwise 
Table 3: Descriptive Statistics Separated By Write-Off And Non-Write-Off Firm-Years

\begin{tabular}{|c|c|c|c|c|c|c|}
\hline & \multicolumn{3}{|c|}{ Non-Write-Off Firm-Years $(\mathrm{N}=319)$} & \multicolumn{3}{|c|}{ Write-Off Firm-Years (N=486) } \\
\hline & $\begin{array}{c}\text { Mean } \\
\text { (P-Value) }\end{array}$ & Median & $\begin{array}{l}\text { Standard } \\
\text { Deviation }\end{array}$ & Mean & Median & $\begin{array}{l}\text { Standard } \\
\text { Deviation }\end{array}$ \\
\hline \multirow[t]{2}{*}{ INCOME $_{\text {it }}$} & 0.07 & 0.06 & 0.14 & 0.02 & 0.03 & 0.14 \\
\hline & $(0.000)$ & & & & & \\
\hline \multirow[t]{2}{*}{$\mathrm{OCF}_{\mathrm{it}}$} & 0.10 & 0.09 & 0.13 & 0.08 & 0.08 & 0.09 \\
\hline & $(0.144)$ & & & & & \\
\hline \multirow[t]{2}{*}{ MTB $_{\text {it }}$} & 2.69 & 1.98 & 2.22 & 2.47 & 1.88 & 2.63 \\
\hline & $(0.217)$ & & & & & \\
\hline \multirow[t]{2}{*}{\begin{tabular}{|l|} 
BIGBATH $_{\text {it }}$ \\
\end{tabular}} & -0.02 & 0.00 & 0.08 & -0.03 & 0.00 & 0.07 \\
\hline & $(0.719)$ & & & & & \\
\hline \multirow[t]{2}{*}{ INCSMOOTH $_{\text {it }}$} & 0.05 & 0.01 & 0.14 & 0.05 & 0.01 & 0.10 \\
\hline & $(0.370)$ & & & & & \\
\hline \multirow[t]{2}{*}{ DTA $_{\text {it }}$} & 16.38 & 13.69 & 14.74 & 23.74 & 21.88 & 16.95 \\
\hline & $(0.000)$ & & & & & \\
\hline \multirow[t]{2}{*}{$\mathrm{MC}_{\mathrm{it}}$} & 0.19 & 0.00 & 0.39 & 0.29 & 0.00 & 0.45 \\
\hline & $(0.031)$ & & & & & \\
\hline \multirow[t]{2}{*}{$\mathrm{EBB}_{\mathrm{it}}$} & 0.90 & 1.00 & 0.31 & 0.80 & 1.00 & 0.40 \\
\hline & $(0.012)$ & & & & & \\
\hline \multirow[t]{2}{*}{ FIRMSIZE $_{\text {it }}$} & 13.18 & 13.04 & 1.46 & 14.70 & 14.45 & 1.91 \\
\hline & $(0.000)$ & & & & & \\
\hline \multirow[t]{2}{*}{$\mathrm{BIG}_{\text {it }}$} & 0.75 & 1.00 & 0.43 & 0.88 & 1.00 & 0.32 \\
\hline & $(0.000)$ & & & & & \\
\hline \multirow[t]{2}{*}{ LISTING $_{\text {it }}$} & 0.05 & 0.00 & 0.22 & 0.14 & 0.00 & 0.35 \\
\hline & $(0.000)$ & & & & & \\
\hline
\end{tabular}

Table 3 shows the descriptive statistics differentiated by write-off and non-write-off firm-years. Significance levels of differences in means are reported in parentheses. 
Table 4: Correlation Analysis

\begin{tabular}{|c|c|c|c|c|c|c|c|c|c|c|c|c|}
\hline & $\mathbf{W O}_{\text {it }}$ & INCOME $_{\text {it }}$ & $\mathrm{OCF}_{\text {it }}$ & MTB $_{\text {it }}$ & BIGBATH $_{\text {it }}$ & INCSMOOTH $_{\text {it }}$ & DTA $_{\text {it }}$ & $\mathrm{MC}_{\mathrm{it}}$ & $\mathbf{E B B}_{\text {it }}$ & FIRMSIZE $_{\text {it }}$ & BIG4 $_{\text {it }}$ & LISTING $_{\text {it }}$ \\
\hline \multirow[t]{2}{*}{$\mathbf{W O}_{\text {it }}$} & 1.000 & -0.229 & -0.062 & -0.065 & -0.049 & -0.062 & 0.223 & 0.107 & -0.126 & 0.418 & 0.177 & 0.141 \\
\hline & & $(0.000)$ & $(0.079)$ & $(0.064)$ & $(0.165)$ & $(0.079)$ & $(0.000)$ & $(0.031)$ & $(0.012)$ & $(0.000)$ & $(0.000)$ & $(0.000)$ \\
\hline \multirow[t]{2}{*}{ INCOME $_{\text {it }}$} & -0.193 & 1.000 & 0.492 & 0.450 & 0.415 & 0.404 & -0.344 & -0.137 & 0.085 & -0.105 & -0.029 & -0.036 \\
\hline & $(0.000)$ & & $(0.000)$ & $(0.000)$ & $(0.000)$ & $(0.000)$ & $(0.000)$ & $(0.006)$ & $(0.091)$ & $(0.003)$ & $(0.415)$ & $(0.307)$ \\
\hline \multirow[t]{2}{*}{$\mathrm{OCF}_{\text {it }}$} & -0.052 & 0.417 & 1.000 & 0.387 & 0.189 & 0.175 & -0.190 & -0.093 & 0.000 & -0.048 & 0.008 & 0.026 \\
\hline & $(0.144)$ & $(0.000)$ & & $(0.000)$ & $(0.000)$ & $(0.000)$ & $(0.000)$ & $(0.060)$ & $(0.994)$ & $(0.174)$ & $(0.824)$ & $(0.463)$ \\
\hline \multirow[t]{2}{*}{ MTB $_{\text {it }}$} & -0.044 & 0.295 & 0.301 & 1.000 & 0.271 & 0.294 & -0.200 & -0.039 & 0.049 & -0.114 & -0.019 & -0.057 \\
\hline & $(0.217)$ & $(0.000)$ & $(0.000)$ & & $(0.000)$ & $(0.000)$ & $(0.000)$ & $(0.433)$ & $(0.326)$ & $(0.001)$ & $(0.586)$ & $(0.108)$ \\
\hline \multirow[t]{2}{*}{ BIGBATH $_{\text {it }}$} & -0.013 & 0.371 & 0.178 & -0.004 & 1.000 & 0.709 & -0.075 & -0.071 & -0.001 & 0.030 & 0.030 & -0.018 \\
\hline & $(0.719)$ & $(0.000)$ & $(0.000)$ & $(0.900)$ & & $(0.000)$ & $(0.033)$ & $(0.151)$ & $(0.982)$ & $(0.392)$ & $(0.393)$ & $(0.605)$ \\
\hline \multirow[t]{2}{*}{ INCSMOOTH $_{\text {it }}$} & -0.032 & 0.407 & 0.030 & 0.173 & 0.151 & 1.000 & -0.197 & -0.027 & -0.041 & -0.188 & -0.008 & -0.067 \\
\hline & $(0.370)$ & $(0.000)$ & $(0.399)$ & $(0.000)$ & $(0.000)$ & & $(0.000)$ & $(0.588)$ & $(0.415)$ & $(0.000)$ & $(0.829)$ & $(0.058)$ \\
\hline \multirow[t]{2}{*}{ DTA $_{\text {it }}$} & 0.218 & -0.318 & -0.146 & -0.089 & -0.033 & -0.110 & 1.000 & 0.081 & -0.098 & 0.344 & -0.043 & 0.105 \\
\hline & $(0.000)$ & $(0.000)$ & $(0.000)$ & $(0.012)$ & $(0.351)$ & $(0.002)$ & & $(0.102)$ & $(0.051)$ & $(0.000)$ & $(0.221)$ & $(0.003)$ \\
\hline \multirow[t]{2}{*}{$\mathbf{M C}_{\mathrm{it}}$} & 0.107 & -0.078 & -0.090 & 0.071 & 0.011 & -0.030 & 0.103 & 1.000 & -0.094 & -0.033 & -0.030 & 0.038 \\
\hline & $(0.031)$ & $(0.113)$ & $(0.069)$ & $(0.153)$ & $(0.823)$ & $(0.541)$ & $(0.036)$ & & $(0.117)$ & $(0.499)$ & $(0.541)$ & $(0.448)$ \\
\hline \multirow[t]{2}{*}{ EBB $_{\text {it }}$} & \begin{tabular}{|l|}
-0.126 \\
\end{tabular} & 0.090 & -0.009 & 0.042 & -0.040 & 0.003 & -0.089 & -0.094 & 1.000 & 0.005 & -0.145 & 0.074 \\
\hline & $(0.012)$ & $(0.073)$ & $(0.856)$ & $(0.403)$ & $(0.428)$ & $(0.952)$ & $(0.074)$ & $(0.117)$ & & $(0.927)$ & $(0.004)$ & $(0.143)$ \\
\hline \multirow[t]{2}{*}{ FIRMSIZE $_{\mathrm{it}}$} & 0.394 & 0.022 & -0.011 & -0.148 & 0.108 & -0.159 & 0.263 & -0.008 & 0.026 & 1.000 & 0.290 & 0.404 \\
\hline & $(0.000)$ & $(0.536)$ & $(0.764)$ & $(0.000)$ & $(0.002)$ & $(0.000)$ & $(0.000)$ & $(0.879)$ & $(0.609)$ & & $(0.000)$ & $(0.000)$ \\
\hline \multirow[t]{2}{*}{ BIG4 $_{\text {it }}$} & 0.177 & -0.004 & 0.057 & 0.011 & 0.027 & -0.031 & -0.089 & -0.030 & -0.145 & 0.280 & 1.000 & 0.153 \\
\hline & $(0.000)$ & $(0.911)$ & $(0.105)$ & $(0.763)$ & $(0.449)$ & $(0.388)$ & $(0.011)$ & $(0.541)$ & $(0.004)$ & $(0.000)$ & & $(0.000)$ \\
\hline \multirow[t]{2}{*}{ LISTING $_{\text {it }}$} & 0.141 & -0.001 & 0.011 & -0.085 & 0.033 & -0.055 & 0.092 & 0.038 & 0.074 & 0.508 & 0.153 & 1.000 \\
\hline & $\begin{array}{l}(0.000) \\
\end{array}$ & $(0.969)$ & $(0.763)$ & $(0.016)$ & $(0.351)$ & $(0.120)$ & $(0.009)$ & $(0.448)$ & $(0.143)$ & $(0.000)$ & $(0.000)$ & \\
\hline
\end{tabular}

Table 4 exhibits the pair wise Pearson correlation coefficients in the lower left triangle. Pair wise Spearman correlation coefficients are provided in the upper right triangle. Significance levels are reported below in parenthesis. 
Table 5: Panel Probit Regression Results



Model 1:

$$
\begin{aligned}
\operatorname{Pr}\left(W O_{i t}\right. & =1)=\beta_{0}+\beta_{1} I_{N C O M E_{t}}+\beta_{2} O C F_{i t}+\beta_{3} M T B_{i t} \\
& +\beta_{4} \text { BIGBATH }_{i t}+\beta_{5} \text { INCSMOOTH }_{t}+\beta_{6} \text { DTA }_{i t} \\
& +\beta_{7} \text { FIRMSIZE }_{t t}+\beta_{8} \text { BIG }_{i t}+\beta_{9} \text { ISSTING }_{i t}+\beta_{10-15} \text { YEAR }_{t}+\varepsilon_{i t}
\end{aligned}
$$

Model 2:

$$
\begin{aligned}
\operatorname{Pr}\left(W O_{i t}\right. & =1)=\beta_{0}+\beta_{1} I_{N C O M E_{i t}}+\beta_{2} O C F_{i t}+\beta_{3} M_{i t} \\
& +\beta_{4} \text { BIGBATH }_{i t}+\beta_{5} \text { INCSMOOTH }_{i t}+\beta_{6} \text { DTA }_{i t}+\beta_{7} M C_{i t} \\
& +\beta_{8} \text { FIRMSIZE }_{i t}+\beta_{9} \text { BIG4 }_{i t}+\beta_{10} \text { ISSTING }_{i t}+\beta_{11-16} \text { YEAR }_{t}+\varepsilon_{i t}
\end{aligned}
$$


Model 3:

$$
\begin{aligned}
\operatorname{Pr}\left(W O_{i t}\right. & =1)=\beta_{0}+\beta_{1} I_{N C O M E_{i t}+\beta_{2} O C F_{i t}+\beta_{3} \text { MTB }_{i t}} \\
& +\beta_{4} \text { BIGBATH }_{i t}+\beta_{5} \text { INCSMOOTH }_{i t}+\beta_{6} \text { DTA }_{i t}+\beta_{7} E B B_{i t} \\
& +\beta_{8} \text { FIRMSIZE }_{t}+\beta_{9} \text { BIG }_{i t}+\beta_{10} \text { LISTING }_{i t}+\beta_{11-16} \text { YEAR }_{t}+\varepsilon_{i t}
\end{aligned}
$$

\begin{tabular}{|c|c|c|c|c|c|c|}
\hline & & $\begin{array}{c}\text { Model 1 } \\
\text { with ROA } \\
\text { it }\end{array}$ & $\begin{array}{c}\text { Model } 1 \\
\text { with SALES } \\
\text { it }\end{array}$ & $\begin{array}{l}\text { Model } 1 \\
\text { with } \\
\text { MTBCHANGE }_{\text {it }}\end{array}$ & $\begin{array}{l}\text { Model } 1 \\
\text { Logit }\end{array}$ & $\begin{array}{l}\text { Model 1 } \\
\text { excluding } \\
2005\end{array}$ \\
\hline & $\begin{array}{l}\text { Predicted } \\
\text { Sign }\end{array}$ & $\begin{array}{c}\text { Coefficient } \\
\text { (Z-Statistic) }\end{array}$ & $\begin{array}{l}\text { Coefficient } \\
\text { (Z-Statistic) }\end{array}$ & $\begin{array}{c}\text { Coefficient } \\
\text { (Z-Statistic) }\end{array}$ & $\begin{array}{c}\text { Coefficient } \\
\text { (Z-Statistic) }\end{array}$ & $\begin{array}{l}\text { Coefficient } \\
\text { (Z-Statistic) }\end{array}$ \\
\hline & & $\mathrm{N}=805$ & $\mathrm{~N}=805$ & $\mathrm{~N}=805$ & $\mathrm{~N}=805$ & $\mathrm{~N}=721$ \\
\hline \multirow[t]{2}{*}{ CONSTANT } & $+/-$ & $-7.807 * * *$ & $-7.974 * * *$ & $-7.815 * * *$ & $-14.543 * * *$ & $-8.591 * * *$ \\
\hline & & $(-6.64)$ & $(-6.49)$ & $(-6.76)$ & $(-6.77)$ & $(-6.68)$ \\
\hline \multicolumn{7}{|l|}{ IMPAIRMENT } \\
\hline \multirow[t]{2}{*}{ INCOME $_{\text {it }}$} & - & -- & $-4.908 * * *$ & $-5.06 * * *$ & $-9.918 * * *$ & $-5.227 * * *$ \\
\hline & & -- & $(-6.10)$ & $(-6.09)$ & $(-6.07)$ & $(-6.05)$ \\
\hline \multirow[t]{2}{*}{$\mathrm{ROA}_{\text {it }}$} & - & $-0.048 * * *$ & -- & -- & -- & -- \\
\hline & & $(-5.24)$ & -- & -- & -- & -- \\
\hline \multirow[t]{2}{*}{$\mathrm{OCF}_{\text {it }}$} & - & 0.824 & -- & $1.34 *$ & 1.899 & 0.934 \\
\hline & & $(1.05)$ & -- & $(1.69)$ & $(1.34)$ & $(1.11)$ \\
\hline \multirow[t]{2}{*}{ SALES $_{\text {it }}$} & - & -- & -0.880 & -- & -- & -- \\
\hline & & -- & $(-0.58)$ & -- & -- & -- \\
\hline \multicolumn{7}{|c|}{ REPORTING INCENTIVES } \\
\hline \multirow[t]{2}{*}{$\mathrm{MTB}_{\text {it }}$} & - & 0.055 & $0.082 * *$ & - & $0.135^{*}$ & 0.063 \\
\hline & & $(1.39)$ & $(2.02)$ & -- & $(1.86)$ & $(1.54)$ \\
\hline \multirow[t]{2}{*}{ MTBCHANGE $_{\text {it }}$} & + & -- & -- & -0.027 & -- & -- \\
\hline & & -- & -- & $(-0.33)$ & -- & -- \\
\hline \multirow[t]{2}{*}{ BIGBATH $_{\text {it }}$} & - & 0.581 & 0.599 & 0.318 & 0.977 & 0.309 \\
\hline & & $(0.53)$ & $(0.56)$ & $(0.30)$ & $(0.50)$ & $(0.28)$ \\
\hline \multirow[t]{2}{*}{ INCSMOOTH $_{\text {it }}$} & + & $2.255 * * *$ & $2.640 * * *$ & $2.912 * * *$ & $5.635 * * *$ & $2.871 * * *$ \\
\hline & & $(3.40)$ & $(3.93)$ & $(4.33)$ & $(4.03)$ & $(4.14)$ \\
\hline \multirow[t]{2}{*}{ DTA $_{\text {it }}$} & - & 0.100 & 0.004 & 0.005 & 0.006 & 0.004 \\
\hline & & $(1.53)$ & $(0.60)$ & $(0.79)$ & $(0.54)$ & $(0.54)$ \\
\hline \multicolumn{7}{|c|}{ CONTROL VARIABLES } \\
\hline \multirow[t]{2}{*}{ FIRMSIZE $_{\text {it }}$} & + & $0.542 * * *$ & $0.570 * * *$ & $0.551 * * *$ & $1.015 * * *$ & $0.602 * * *$ \\
\hline & & $(6.26)$ & $(6.43)$ & $(6.41)$ & $(6.42)$ & $(6.31)$ \\
\hline \multirow[t]{2}{*}{$\mathrm{BIG}_{\text {it }}$} & + & 0.371 & 0.322 & 0.371 & 0.587 & 0.369 \\
\hline & & $(1.21)$ & $(1.06)$ & $(1.23)$ & $(1.11)$ & $(1.17)$ \\
\hline \multirow[t]{2}{*}{ LISTING $_{\text {it }}$} & + & -0.693 & $-0.765 *$ & $-0.741 *$ & $-1.345^{*}$ & $-0.912 *$ \\
\hline & & $(-1.53)$ & $(-1.70)$ & $(-1.66)$ & $(-1.70)$ & $(-1.93)$ \\
\hline Log Likelihood & & -390.960 & -383.465 & -384.417 & -381.662 & -343.635 \\
\hline Wald-statistic & & 0.000 & 0.000 & 0.000 & 0.000 & 0.000 \\
\hline \multicolumn{2}{|c|}{ McFadden's Pseudo $\mathrm{R}^{2}$} & 0.277 & 0.291 & 0.289 & 0.294 & 0.290 \\
\hline \multicolumn{7}{|c|}{$* * * * * *$ denotes significance at $<0.01,<0.05,<0.1$ levels respectively. } \\
\hline \multicolumn{7}{|c|}{$\begin{array}{l}\text { Table } 6 \text { shows our sensitivity analysis. We based our sensitivity tests on our model } 1 \text { with a sample size of } 805 \text { firm-year } \\
\text { observations. The exclusion of } 2005 \text { reduces the sample to } 721 \text { firm-years. Parameter estimates are based on model } 1 \text { described in } \\
\text { Table } 5 \text { with the variations indicated in the header of the table. }\end{array}$} \\
\hline
\end{tabular}

$* * * * * *$ denotes significance at $<0.01,<0.05,<0.1$ levels, respectively.

Table 6: Sensitivity Analysis 